\title{
Blood and virus detection on barber clippers
}

Z Spengane, ${ }^{1} \mathrm{MB}$ ChB, MPhil; S Korsman, ${ }^{2} \mathrm{FC}$ Path; K Mkentane, ${ }^{1} \mathrm{MSc}, \mathrm{PhD}$; L M Davids, ${ }^{3} \mathrm{PhD}(\mathrm{Med}) ; \mathrm{W}$ Zemanay, ${ }^{3} \mathrm{BSc} \mathrm{Hons}, \mathrm{PhD}$; M Africa, ${ }^{3}$ BTech; S Mbhele, ${ }^{3}$ MSc; M Nicol, ${ }^{3}$ FCPath, PhD; F Gumedze $,{ }^{4} \mathrm{MSc}, \mathrm{PhD} ; \mathrm{D}$ Ngwanya, ${ }^{1}$ FC Derm; N P Khumalo, ${ }^{1}$ FC Derm, PhD

\author{
${ }^{1}$ Division of Dermatology, Faculty of Health Sciences, University of Cape Town, South Africa \\ ${ }^{2}$ Division of Medical Virology, Faculty of Health Sciences, University of Cape Town, and National Health Laboratory Service, Groote Schuur \\ Hospital, Cape Town, South Africa \\ ${ }^{3}$ Division of Medical Microbiology and Institute for Infectious Diseases and Molecular Medicine, Faculty of Health Sciences, University of \\ Cape Town, South Africa \\ ${ }^{4}$ Department of Statistical Sciences, Faculty of Science, University of Cape Town, South Africa
}

Corresponding author: N P Khumalo(n.khumalo@uct.ac.za)

\begin{abstract}
Background. Bleeding from the popular clean-shave 'chiskop' haircut was recently reported as prevalent in South Africa (SA), a country with 6.9 million HIV-infected people.

Objectives. To investigate the prevalence of barber hair clipper contamination with blood and HIV and hepatitis B viruses.

Methods. Fifty barbers from three townships in Cape Town, SA, were invited to participate. One clipper from each barber was collected immediately after it had been used for a clean-shave haircut. Each clipper was rinsed with phosphate-buffered saline and then submerged in viral medium. The polymerase chain reaction (PCR) was used to identify the blood-specific RNA marker haemoglobin beta (HBB), hepatitis B virus (HBV) and HIV.

Results. The clean-shave haircut was the most common haircut requested by clients (78\%). Of the clippers collected, $42 \%$ were positive for $\mathrm{HBB}$, confirming detection of blood, none were positive for HIV, and 4 (8\%) were positive for HBV. Two clippers (clippers 16 and 20) were positive on qualitative HBV PCR. HBV DNA from clipper 16 clustered with genotype A sequences from SA, India, Brazil and Martinique, while clipper 20 clustered with SA genotype D sequences. The clipper 20 sequence was identical to a subtype D sequence (GenBank accession AY233291) from Gauteng, SA.

Conclusion. This study confirms that there is significant contamination of barber hair clippers with blood and blood-borne viruses. Hepatitis B was detected with enough DNA copies to pose a risk of transmitting infection. Although HIV was not detected in this small study, the risk of transmission should be quantified. Further studies to investigate barber clipper sterilisation practices and whether the clean-shave hairstyle is an independent risk factor for HIV, HBV and hepatitis C virus infections are warranted. Public education on individual clipper ownership (as is the case with a toothbrush) should be advocated for clean-shave and blade-fade haircuts.
\end{abstract}

S Afr Med J 2018;108(4):278-282. DOI:10.7196/SAMJ.2018.v108i4.12830

Human scalp hair varies significantly in curvature, and individuals of African ancestry have hair with the tightest curl. ${ }^{[1,2]}$ Population data suggest that hair follicles with this texture are prone to specific forms of alopecia (hair loss) that predominantly affect women (traction alopecia ${ }^{[3]}$ and central centrifugal cicatricial alopecia ${ }^{[4]}$ ) and men (folliculitis keloidalis nuchea ${ }^{[4]}$ ).

Hairstyle trends for men have changed over the years, from the 'big afros' of the 1960s and 1970s to the 'blade-fade' haircut or German cut (originally worn by working class men in the 1920s and popular among Hitler's Wehrmacht soldiers in Germany, hence the name) that became popular in the 1990s and the current clean-shave or 'chiskop' that became fashionable at the turn of the last century and is worn by $70 \%$ of black men in Cape Town townships. ${ }^{[4]}$ The chiskop is worn by the majority of black men in South Africa (SA) and the African diaspora. Besides being a trend, this haircut is part of certain cultural rituals in various African and Indian (tonsure) tribes. The haircut is achieved either by using a razor blade or by pressing the metal shears of an electric clipper directly onto the scalp without using the manufacturer-supplied plastic stages (combs). This gives a clean-shave haircut similar to that achieved using a razor blade.

Shaving pimples, more commonly seen in the beard area, also occur on the scalp as transient papules and pustules. However, when these pimples evolve into permanent keloids on the back (nucheal) scalp they are characteristic of folliculitis keloidalis nuchea (FKN), also commonly and incorrectly called acne keloidalis nuchea, which has a prevalence of $10.5 \%$ in males and $0.1 \%$ females aged $>18$ years. ${ }^{[4]}$ The prevalence of FKN was found to be highest in individuals whose hair had been cut with razors (10.7\%), followed by clippers (5.9\%), while no case was seen in those who used depilatory creams. ${ }^{[5]}$

A history of haircut-associated bleeding as a result of clean-shave haircuts was an unexpected finding in $32 \%$ of male participants from a population study ${ }^{[4]}$ in which HIV status was unknown. This was later confirmed in a later study where a history of bleeding was reported in $24.8 \%$ of HIV-positive men. ${ }^{[5,6]}$ Invisible bleeding was recently detected from scalp swabs after professional clean-shave haircuts (with no visible injury on the scalp when examined by a dermatologist) in $37 \%$ of participants using genetic testing for bloodspecific RNA markers (albumin and haemoglobin beta (HBB)). ${ }^{[7]}$ The potential transmission of blood-borne viruses such as hepatitis B (HBV) and HIV is most concerning. A study in Ethiopia reported that sharing shaving equipment in barber shops is common practice, ${ }^{[8]}$ and an accidental scratch by sharp equipment in barber shops may create an opportunity for HIV and other blood-borne pathogens to enter the body. ${ }^{[8]}$ Currently there is no study in the literature that has looked at informal barber practices in SA townships. The prevalence of contamination of haircut clippers or razors with blood and bloodborne viruses in our setting is unknown. Methods of sterilisation 
or disinfection of barber instruments in our townships have been speculated on but not verified.

\section{Objectives}

The primary objective was to test clippers that had just been used for a haircut for blood and viruses. Our intention was to detect the prevalence of clipper contamination with blood, HIV and HBV, to ascertain whether barbers who mainly cut clean-shave chiskop haircuts caused more or less haircut-associated bleeding than barbers who did longer haircuts, i.e. at a distance from the scalp, and to investigate the cleaning methods used by barbers.

\section{Methods}

This was a prospective cross-sectional study. Aerial maps were used to sample 50 barber shops from three townships, the populations of which reflect the racial (apartheid) segregation of the previous SA government. Langa and Gugulethu townships have a population of predominantly black African ancestry and Bonteheuwel a population of predominantly mixed-race ancestry. The maps of Gugulethu and Langa, the two larger townships, were divided into four, then five barbers were selected from each section. The smaller Bonteheuwel township was divided into two, and five barbers were selected from each section. Basic demographic data were collected. Consenting barbers then performed one haircut, immediately after which they gave their clipper to the investigator; in exchange they received a new clipper. Methods used by the barbers to clean the clippers after use on each client were documented.

Each clipper was placed into a ziplock bag at room temperature, after which the bag was sealed and taken to a laboratory for virological sampling of the clipper. At the laboratory the clipper was submerged in a petri dish with $1.5 \mathrm{~mL}$ of viral medium, plugged into an electrical port and switched on to allow maximum wash through the teeth. The viral medium was then aspirated using a pipette and the residue was placed into a tube and stored at $-80^{\circ} \mathrm{C}$ until viral analysis.

Total nucleic acid was extracted from $800 \mu \mathrm{L}$ of wash using the EasyMag system (bioMérieux, Netherlands). For HIV testing, qualitative nested reverse-transcription polymerase chain reaction (RT-PCR) was performed to detect HIV RNA present, as follows.

A 160 bp region of gag (nucleotide position $1494-1653$ on the reference HIV HXB2 genome) was amplified by onestep RT-PCR using the SuperScript One-Step RT-PCR System with Platinum Taq (Invitrogen, Thermo Fisher Scientific, USA) in $50 \mu \mathrm{L}$ final volume reaction with primers GAG A (forward, 5'-AGAGAACCAAGGGGAAGTGA-3') and GAG B (reverse, 5'-TCTCTAAAGGGTTCCTTTGG-3') each at $0.6 \mu \mathrm{M}$, and $10 \mu \mathrm{L}$ nucleic acid eluate. Reverse transcription was carried out at $50^{\circ} \mathrm{C}$ for 30 minutes and PCR at $94^{\circ} \mathrm{C}$ for 2 minutes, followed by 40 cycles at $94^{\circ} \mathrm{C}$ for 25 seconds, $40^{\circ} \mathrm{C}$ for 30 seconds and $68^{\circ} \mathrm{C}$ for 45 seconds, with a final extension step of $68^{\circ} \mathrm{C}$ for 7 minutes. Nested PCR was performed using SuperTherm Taq DNA polymerase (Separation Scientific, SA) in a $50 \mu \mathrm{L}$ final reaction volume with primers GAG C (forward, 5'-CATAGCAGGAACTACTAGTA-3') and GAG D (reverse, 5'-TCCTTGTCTTATGTCCAGAA-3'), each at $1 \mu \mathrm{M}$, with $2 \mu \mathrm{L}$ prenested PCR product. PCR cycling conditions were the same as described above. PCR products were analysed under ultraviolet (UV) light after $2 \%$ agarose gel electrophoresis. ${ }^{[6,9]}$

For HBV testing, $600 \mu \mathrm{L}$ of wash was tested with the quantitative Roche COBAS AmplPrep/COBAS TaqMan HBV Test, version 2 (Roche Diagnostics, Germany). Samples with detectable HBV DNA were then tested on a qualitative nested $\mathrm{PCR}^{[11]}$ to obtain products for sequencing, as follows. A 189 bp region of the HBV pre-S1 gene was amplified by nested PCR using SuperTherm Taq DNA polymerase (Separation Scientific) in a $50 \mu \mathrm{L}$ final reaction volume. First-round primers were as follows: HBV1 (forward) TGGGAACAAGAKCTAC; HBV2 (reverse) GAACTGGAGCCACCAG; the final primer concentration was $0.4 \mu \mathrm{M}$. Nested PCR primers were as follows: HBV3 (forward) AATCCMGATTGGGACYTCAA; HBV4 (reverse) TCCTRACTGSCGATTGGT; final primer concentration $1 \mu \mathrm{M}$. Cycling conditions were identical for both rounds, and were as follows: $94^{\circ} \mathrm{C}$ for 2 minutes, followed by 35 cycles of $94^{\circ} \mathrm{C}$ for 20 seconds, $50^{\circ} \mathrm{C}$ for 30 seconds and $72^{\circ} \mathrm{C}$ for 45 seconds, with a final extension step of $72^{\circ} \mathrm{C}$ for 7 minutes. PCR products were analysed under UV light after $2 \%$ agarose gel electrophoresis. Both qualitative HIV and HBV PCRs were performed on the Applied Biosystems GeneAmp PCR System 9700 (Applied Biosystems, USA).

HBV PCR products obtained were sent to Inqaba Biotechnical Industries (SA) for bidirectional Sanger sequencing. Chromatograms were edited in FinchTV (Geospiza, USA). Sequences were aligned using ClustalX ${ }^{[12]}$ and manipulated in BioEdit. ${ }^{[13]}$ The maximumlikelihood tree was drawn from an alignment of 188 nucleotide positions in MEGA6 $6^{[14]}$ using the Tamura-Nei evolutionary model..$^{[15]}$ Bootstrap support was calculated with 1000 replicates.

For comparison, HBV sequences representing most genotypes were selected from GenBank, including sequences from SA. The following sequences, with GenBank accession numbers listed by genotype, were chosen to represent the different genotypes: genotype A: AY576430, AY576434, GQ355536, GQ355565, GQ355572, GQ355575, HE974375, HE974376, HQ646554, HQ646556, JF784220, KC752150, KF476003, KF476015, KF476018 and X51970; genotype B: AB033554, AF100309 and D00329_JP; genotype C: AB644284, AB644286 and GQ184326; genotype D: AF280817, AY233291, AY233295, AY576433, EU594430, FJ904447, GQ184322, GQ205389, HE974377, JX898722, KC012652, KF170740 and KF476030; genotype E: AP007262, DQ060824 and HE974380; genotype F: AB116654 and AF223965; genotype G: AP007264 and GU565217; genotype H: AB298362 and AY090454; genotype I: FJ023674 and FJ882615. Orangutan HBV, AF193864, was used to root the tree.

For the blood-specific markers, hair clippers were rinsed with phosphate-buffered saline (PBS) and RNA was extracted from the PBS using the QIAgen RNeasy kit (Qiagen, SA). Briefly, total RNA was extracted according to the manufacturer's instructions. The eluted RNA was used for CDNA synthesis with a reverse-transcription enzyme (Fermentas, SA) and random hexamer primers. Conventional PCR was performed using primer sets for the blood-specific marker, with HBB RNA primer sequences as follows: (forward) CAC CTG GAC AAC CTC AAG; (reverse) AAT TCAC CCC ACC AGT GCA. PCR products were detected with a 3130xl Genetic Analyzer (Applied Biosystems). Briefly, a $1 \mu \mathrm{L}$ aliquot of neat PCR product was added to $8 \mu \mathrm{L}$ Hi-Di Formamide and $0.2 \mu \mathrm{L}$ of GeneScan 500 Rox size standard (Applied Biosystems). The samples were heated to $95^{\circ} \mathrm{C}$ before being loaded onto the analyser. The conditions used for capillary electrophoresis were as follows: samples were injected through a 36 $\mathrm{cm}$ capillary filled with pop7 polymer, (ThermoFisher Scientific, USA) at a temperature of $60^{\circ} \mathrm{C}$. Samples were injected for 3 seconds using an injection voltage of $1.2 \mathrm{kV}$ and electrophoresed for $\sim 20$ minutes. The raw data were analysed using GeneMapper Software v4.0 (ThermoFisher Scientific).

\section{Ethics clearance}

Ethics approval for this study was obtained from the Human Research Ethics Committee, Faculty of Health Sciences, University of Cape Town (ref. no. 208/2013). 


\section{Results}

All invited barbers agreed to participate, and a total of 50 clippers were collected. Twenty-one (42\%) of all clippers were positive for the blood RNA marker HBB (5/20, 7/10 and 9/20 from townships 1 , 2 and 3, respectively). Clippers from township 2 had a significantly higher prevalence of blood contamination at $72 \%$, compared with $33 \%$ of those from townships 1 and 3 ( $p=0.023$ ). Table 1 shows the characteristics of the study participants according to hairstyle.

No clippers were positive for HIV. Four clippers (8\%) were positive for HBV. Two clippers (clippers 16 and 20) were positive on qualitative HBV PCR. HBV DNA from clipper 16 clustered with genotype A sequences from SA, India, Brazil, and Martinique, while clipper 20 clustered with SA genotype D sequences. The clipper 20 sequence was identical to a subtype D sequence (GenBank accession AY233291) from Gauteng, SA ${ }^{[15]}$ (Fig. 1).

In the communities with a predominantly black African population, townships 1 and 3, the chiskop haircut was the style most commonly requested by clients. In township 2, the population of which is predominantly of mixed-race ancestry, no client requested a chiskop; instead 6 had a brush cut, 3 a blade-fade and 1 a German cut (the scalp margins are shaved with a blade in the blade-fade and with a clipper in the German cut; however, the result is the same). All the barbers cleaned the clippers after each client, but the cleaning agents varied. Most barbers (82\%) used disinfection with methylated spirits after using a brush to remove hair, and $8 \%$ used an open flame. All the barbers who used an open flame to clean their clippers ( $8 \%$ of the total sample) were from township 2 and usually cut the blade-fade style $(p=0.013)$.

\section{Discussion}

Four clippers were contaminated with HBV. The HBV sequences identified are in keeping with other sequences from SA, where the main hepatitis B genotypes are A and D. ${ }^{[15,16]}$ The use of only 188 nucleotide positions for phylogenetic analysis limits the conclusions that can be reached, but is adequate to show that our sequences cluster with sequences obtained from our region by other researchers. We found concentrations of HBV DNA of between $<20$ and 45 IU/ $\mathrm{mL}$ in clipper wash. Welzel et al. ${ }^{[17]}$ calculated a ratio of $1 \mathrm{IU}: 10 \mathrm{DNA}$ copies in their laboratory. The 2009 chronic hepatitis B practice guidelines $^{[18]}$ indicate a ratio of 1 IU:5 DNA copies. This amounts to approximately 300 DNA copies washed from clipper 16 . Levels of HBV DNA in blood vary considerably, depending on the stage of infection, whether infection is acute or chronic, e-antigen positivity or negativity, and other factors. Viral loads are reported to reach as high as $10 \log ^{10} \mathrm{IU} / \mathrm{mL}$ serum/plasma, ${ }^{[19-22]}$ and in our diagnostic laboratory we have seen occasional samples with an estimated viral load of up to $15 \log ^{10} \mathrm{IU} / \mathrm{mL}$ plasma. Viral loads (log copies/ $\mathrm{mL}$ ) of 4.3, 5.9, 6.2 and 5.2 have been reported in urine, saliva, tears and sweat, respectively. ${ }^{[23]}$ Hepatitis B transmission has been linked to body fluids other than blood, ${ }^{[23,24]}$ as well as to the sharing of toothbrushes and razors. ${ }^{[25]}$ The risk of transmission between healthcare workers and patients has been well documented. ${ }^{[2,26]}$ There is therefore a risk of clipper contamination from minor bleeding on the scalp. The infectious dose of hepatitis $B$ has been estimated at $10-100$ viruses. A study in chimpanzees determined the ID50 of HBV (the minimum infectious dose of HBV, or the dose at which $50 \%$ of chimpanzees would be infected ${ }^{[27]}$ ) in five chimpanzees to be $\sim 10$ DNA copies for both genotypes A and C. ${ }^{[27]}$ In a subsequent study, the same team found that a dose of 2.6 - 4.6 DNA copies from pre-acute-phase chimpanzee serum caused infection in $3 / 3$ chimeric mice with transplanted human hepatocytes, while a dose of $200-350$ DNA copies from late acute-phase serum caused infection in only $1 / 3$ mice, ${ }^{[28]}$ suggesting that virus during early acute infection is more able

Table 1. Characteristics of study participants according to hairstyle

\begin{tabular}{|c|c|c|c|c|}
\hline Characteristic & Total, $N(\%)$ & $\begin{array}{l}\text { Clean-shave haircut } \\
\text { barbers, } n \text { (\%) }\end{array}$ & $\begin{array}{l}\text { Other haircut barbers, } \\
n(\%)\end{array}$ & $p$-value ${ }^{*}$ \\
\hline Site & & & & $<0.0001$ \\
\hline Township 1 (Langa) & $20(40.0)$ & $19(48.7)$ & $1(9.1)$ & \\
\hline Township 2 (Bonteheuwel) & $10(20.0)$ & 0 & $10^{\dagger}(90.9)$ & \\
\hline Township 3 (Gugulethu) & $20(40.0)$ & $20(51.3)$ & 0 & \\
\hline Total & 50 & 39 & 11 & \\
\hline Age group of clients serviced (years) & & & & 0.317 \\
\hline $5-17$ & $6(12.0)$ & $6(15.4)$ & 0 & \\
\hline $18-60$ & $44(88.0)$ & $33(84.6)$ & $11(100)$ & \\
\hline Total & 50 & 39 & 11 & \\
\hline Cleaning methods & & & & 0.013 \\
\hline Brush and spirit & $41(82.0)$ & $35(89.8)$ & $6(54.5)$ & \\
\hline Spirit only & $5(10.0)$ & $3(7.7)$ & $2(18.2)$ & \\
\hline Open flame & $4(8.0)$ & $1(2.5)$ & $3(27.3)$ & \\
\hline Total & 50 & 39 & 11 & \\
\hline Hepatitis B virus & & & & 0.643 \\
\hline Positive & $4(8.0)$ & $3(7.7)$ & $1(9.1)$ & \\
\hline Negative & $46(92.0)$ & $36(92.3)$ & $10(90.9)$ & \\
\hline Total & 50 & 39 & 11 & \\
\hline Blood marker (HBB) & & & & 0.023 \\
\hline Positive & $21(42.0)$ & $13(33.3)$ & $8(72.7)$ & \\
\hline Negative & $29(58.0)$ & $26(66.7)$ & $3(27.3)$ & \\
\hline Total & 50 & 39 & 11 & \\
\hline
\end{tabular}




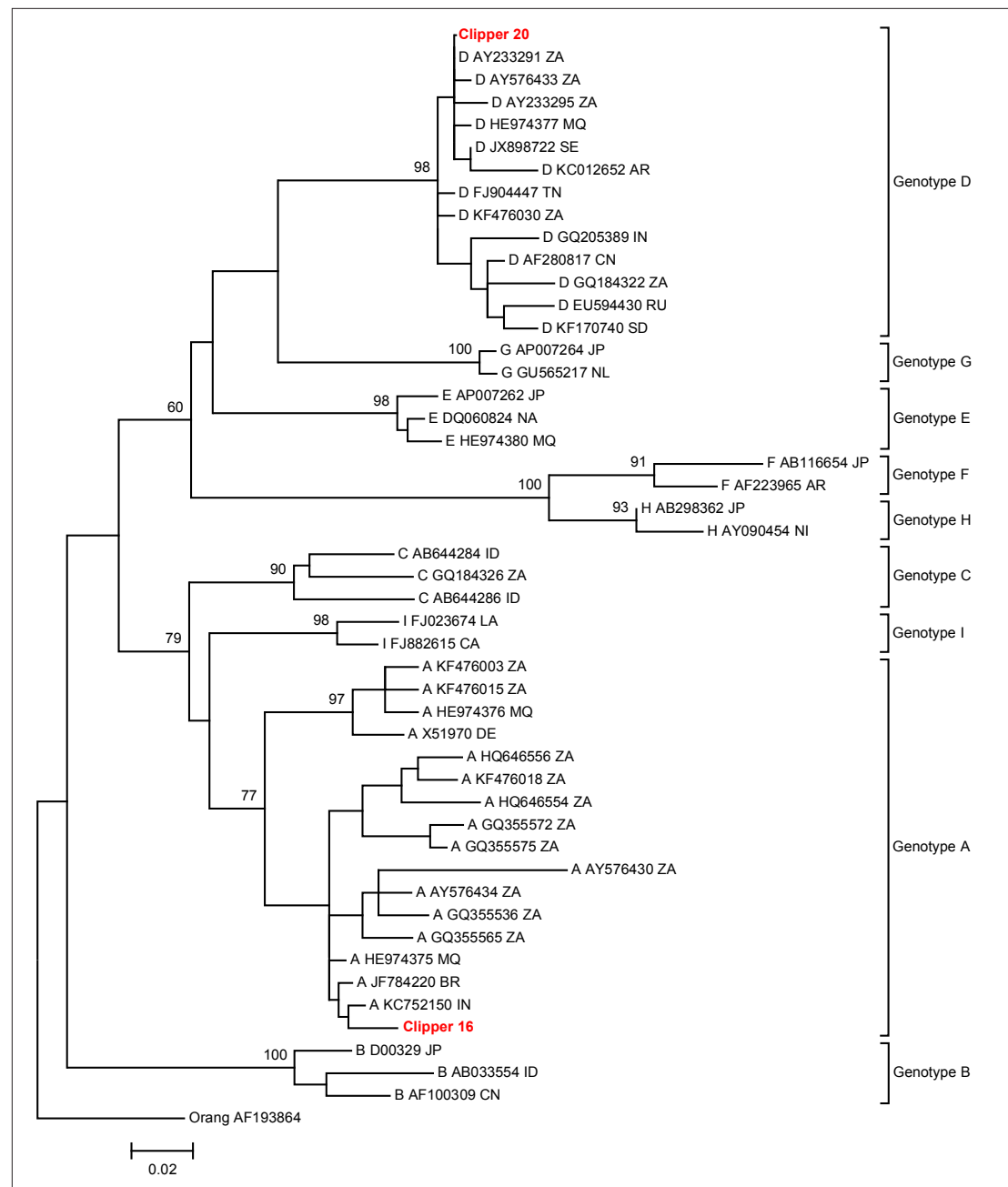

Fig. 1. A maximum-likelihood tree constructed in MEGA6 using an alignment of 188 nucleotide sequences. Selected bootstrap support above $60 \%$ is shown. Study samples are shown in red. The tree is rooted on an orangutan HBV sequence. Sequences for comparison have names starting with genotype, followed by Genbank accession number, ending with country ISO 3166-1 abbreviation (AR = Argentina; $B R=$ Brazil $C A=$ Canada $C N=$ China; $D E=$ Germany; $I D=$ Indonesia; $I N=$ India $L A=$ Laos; $M Q=$ Martinique; $N A=$ Namibia $N I=$ Nicaragua $R U=$ Russia; $S D=$ Sudan; $S E=$ Sweden; $T N=$ Tunisia; $Z A=$ South Africa; scale bar = number of substitutions per site. $)$

to initiate a new infection when transmitted, possibly because in later infection virus in serum may be bound to antibodies.

Commercial methylated spirit contains ethyl alcohol (95\%) and methyl alcohol (5\%), and our findings indicate that it is commonly used to decontaminate barber equipment. Ethyl alcohol and methyl alcohol are not virucidal. The use of open flames for sterilisation has been reported from African countries, ${ }^{[29]}$ but there are no data on efficacy or adequate exposure time. UV light is reported to kill bacteria and viruses effectively ${ }^{[30]}$ Application of UV radiation in biological safety cabinets destroys organisms on the surface of instruments. This microbicidal activity is highly dependent on the wavelength of UV radiation. Modern UV light sterilisation units as well as specific antiviral sprays are used internationally in hair salons. Quaternary ammonium disinfectant cleaners have virucidal activity effective enough to kill herpes simplex virus (HSV) in the presence of blood. ${ }^{[31]}$ HSV has similar properties to HIV, and quaternary ammonium disinfectants could therefore be used to decontaminate surfaces or tools with blood spills. ${ }^{[31]}$ The new generation of accelerated hydrogen peroxide-based environmental surface disinfectants are bactericidal, virucidal, mycobactericidal and fungicidal. ${ }^{[32]}$ The formulation is safe to use and has a high compatibility profile for various materials in addition to being a fastacting intermediate-level disinfectant. ${ }^{[32]}$ In the USA, disinfectant must be approved by the Environmental Protection Agency (EPA), which certifies the efficacy of prod- ucts for infection control. The SA counterpart is the South African Bureau of Standards (SABS). Barbers are encouraged to use EPAor SABS-approved disinfectants for their equipment.

In our study, the low levels of HBV DNA copies on the clippers represent a possible public healthcare risk. We are not aware of cases of HBV or HIV infection resulting from clipper use in our setting. We are unable to identify when each clipper became contaminated with virus, and we do not know how virus levels on clippers decline as the clippers move through hair when they are used on subsequent clients. It is unlikely that the HBV levels detected on the clippers would pose a risk to a client, but closer to the time of the source contamination there may have been levels that did pose such a risk. We are also unable to determine whether the viral DNA levels detected represent infectious virus, or damaged virus no longer able to cause infection. HIV viral loads are typically lower than HBV viral loads, and with similar clipper use this may explain why we did not detect HIV RNA on any clippers. However, closer in time to the source contamination, clippers may have had levels of infectious HIV that could have posed a risk to clients.

The results show that clippers used to mostly cut the longer blade-fade hairstyle were associated with more bleeding markers, although one would expect that the clippers used to cut the clean-shave chiskop would have had more blood markers as a result of the close contact of the blade with the scalp. Our results showed that $72 \%$ of the clippers used to cut the longer blade-shade were positive for $\mathrm{HBB}$, compared with $33 \%$ of the clippers used for the chiskop cut. One plausible explanation could be the small sample size in township 2 . There was a statistically significant difference in cleaning methods used by the barbers cutting the chiskop and blade-fade hairstyles. Of the barbers using clippers to cut the bladefade, only $54 \%$ used a brush and spirit, while $27 \%$ used other methods such as open flames to clean clippers.

While it has been reported that an open flame is used to clean clippers in other African countries, there are no data on the efficacy of this method for disinfection or sterilisation. ${ }^{[29]}$ Many developing countries lack regulating bodies that monitor health practices at barber shops. In developed countries, activities of barbers are regulated through comprehensive training, licensing and monitoring programmes. ${ }^{[8]}$ Lack of knowledge about correct methods of sterilisation and disinfection may be directly 
associated with the lack of formal trade training of the barbers. Barbers' level of education may be a contributory factor.

\section{Study limitations}

The hepatitis B and HIV status of clients was unknown. There are some confounding factors that could have contributed to our results, such as the skill of the barbers in the different townships and the methods they used to cut the hairstyles. The small sample size of township 2 could also have skewed our results. The amount of time spent cleaning the clippers with the different methods was not measured. This is also a possible confounding factor and could have contributed to the results. A study with a bigger sample size could obtain results of better quality.

\section{Conclusions}

This study confirmed that there is significant contamination of barber hair clippers with blood and blood-borne viruses. Hepatitis $B$ was detected with enough DNA copies to pose a risk of infection. Although HIV was not detected, the clinical significance of contamination of clippers with blood, especially with regard to the transmission of blood-borne infections, warrants further study. Further scientific scrutiny is required to quantify infection risk and investigate whether the clean-shave hairstyle is an independent risk factor for HIV, HBV and hepatitis C virus (HCV) infections as well as HIV/HBV and HIV/HCV co-infections. Finally, barber hygiene practices may require upscaling and access to sterilisation facilities. In the meantime, public education recommending individual clipper ownership for close-shave chiskop and blade-fade haircuts should be advocated.

Acknowledgements. Simphiwe Khondlo assisted with data collection in the communities.

Author contributions. Conception and design of the work: NPK, ZS; data collection: ZS, SK ; laboratory data analysis: SK, KM, LMD, WZ, MA, MN; data capturing: SM; data analysis and interpretation: FG, NPK, ZS, MN ; drafting the article: ZS, NPK, SK, MN; critical revision of the article: ZS, NPK, SK, MN, MN; final approval of the version to be published: NPK. Funding. South African Medical Research Council. Conflicts of interest. None.

1. Khumalo NP, Doe PT, Dawber RP, Ferguson DJ. What is normal black African hair? A light and scanning electron-microscopic study. J Am Acad Dermatol 2000;43(5 Pt 1):814-820. https://doi. org/10.1067/mjd.2000.107958

2. Loussouarn G, Garcel AL, Lozano I, et al. Worldwide diversity of hair curliness: A new method of assessment. Int J Dermatol 2007;46(Suppl 1):2-6. https://doi.org/10.1111/j.1365-4632.2007.03453.x 3. Khumalo NP, Jessop S, Gumedze F, Ehrlich R. Hairdressing is associated with scalp disease in African schoolchildren. Br J Dermatol 2007;157(1):106-110. https://doi.org/10.1111/j.1365-2133.2007.07987.x 4. Khumalo NP, Jessop S, Gumedze F, Ehrlich R. Hairdressing and the prevalence of scalp disease in African adults. Br J Dermatol 2007;157(5):981-988. https://doi.org/10.1111/j.1365-2133.2007.08146.x

5. Khumalo NP, Gumedze F, Lehloenya R. Folliculitis keloidalis nuchae is associated with the risk for bleeding from haircuts. Int J Dermatol 2011;50(10):1212-1216. https://doi.org/10.1111/j.13654632.2010.04655.x

6. Khumalo NP, Gantsho N, Gumedze F, Mthebe T. Health risks of the clean-shave chiskop haircut. S Afr Med J 2013;103(7):489-490. https://doi.org/10.7196/SAMJ.6675
7. Khumalo NP, Muthukarapan C, Hardy D, et al. Invisible bleeding from clean-shave haircuts, detection with blood specific RNA markers. Dermatology 2013;227(3):197-201. https://doi. org $/ 10.1159 / 000353529$

8. Biadgelegn F, Belyhun Y, Anagaw B, et al. Potential risk of HIV transmission in barbering practice in Ethiopia: From public health and microbiological perspectives. BMC Public Health 2012;12:707. in Ethiopia: From public health and micro

9. Engelbrecht S, van Rensburg EJ. Detection of southern African human immunodeficiency virus type 1 subtypes by polymerase chain reaction: Evaluation of different primer pairs and conditions. J Virol Methods 1995;55(3):391-400. https://doi.org/10.1016/0166-0934(95)00088-7

10. Hardie DR, Kannemeyer J, Stannard LM. DNA single strand conformation polymorphism identifies five defined strains of hepatitis B virus (HBV) during an outbreak of HBV infection in an oncology unit. J Med Virol 1996;49(1):49-54. https://doi.org/10.1002/(SICI)1096-9071(199605)49:1<49::AIDJMV8>3.0.CO;2-K

11. Thompson JD, Higgins DG, Gibson TJ. CLUSTAL W: Improving the sensitivity of progressive multiple sequence alignment through sequence weighting, position-specific gap penalties and weight matrix choice. Nucleic Acids Res 1994;22(22):4673-4680. https://www.ncbi.nlm.nih.gov/pmc articles/PMC308517/ (accessed 12 March 2018).

12. Hall TA. BioEdit: A user-friendly biological sequence alignment editor and analysis program for Windows 95/98/NT. Nucl Acids Symp Ser 1999:41:95-98. http://brownlab.mbio.ncsu.edu/JWB/ Windows 95/98/NT. Nucl Acids Symp Ser
papers/1999Hall1.pdf (accessed 2 March 2018).

13. Tamura K, Stecher G, Peterson D, Filipski A, Kumar S. MEGA6: Molecular Evolutionary Genetics Analysis version 6.0. Mol Biol Evol 2013;30(12):2725-2729. https://doi.org/10.1093/molbev/mst197 14. Tamura K, Nei M. Estimation of the number of nucleotide substitutions in the control region of $<$ span Tamura K, Nei M. Estimation of the number of nucleotide substitutions in the control region of $<$ span
class="cryg601" id="cryg601_3" $>$ mitochondrial DNA $</$ span $>$ in humans and chimpanzees. Mol Biol Evol 1993;10(3):512-526. https://doi.org/10.1093/oxfordjournals.molbev.a040023

15. Kimbi GC, Kramvis A, Kew MC. Distinctive sequence characteristics of subgenotype Al isolates of hepatitis B virus from South Africa. J Gen Virol 2004;85(Pt 5):1211-1220. https://doi.org/10.1099/ vir.0.19749-0

16. Andersson MI, Maponga TG, Ijaz S, et al. The epidemiology of hepatitis B virus infection in HIV-infected and HIV-uninfected pregnant women in the Western Cape, South Africa. Vaccine 2013;31(47):5579-5584. https://doi.org/10.1016/j.vaccine.2013.08.028

17. Welzel TM, Miley WJ, Parks TL, Goedert JI, Whitby D, Ortiz-Conde BA. Real-time PCR assay for detection and quantification of hepatitis B virus genotypes A to G. J Clin Microbiol 2006;44(9):33253333. https://doi.org/10.1128//CM.00024-06

18. Lok AS, McMahon BJ. Chronic hepatitis B: Update 2009. Hepatology 2009;50(3):661-662. https:// doi.org/10.1002/hep.23190
do.

19. Ciupe SM, Ribeiro RM, Nelson PW, Perelson AS. Modeling the mechanisms of acute hepatitis B virus infection. J Theor Biol 2007;247(1):23-35. https://doi.org/10.1016/j.jtbi.2007.02.017
int. 0 .

20. Ganem D, Prince AM. Hepatitis B virus infection - natural history and clinical consequences. N Engl J Med 2004;350(11):1118-1129. https://doi.org/10.1056/NEJMra031087

21. Ribeiro RM, Lo A, Perelson AS. Dynamics of hepatitis B virus infection. Microbes Infect 2002;4(8):829-835. https://doi.org/S1286457902016039

22. Whalley SA, Murray JM, Brown D, et al. Kinetics of acute hepatitis B virus infection in humans. J Exp Med 2001;193(7):847-854. https://doi.org/10.1084/jem.193.7.847

23. Komatsu H, Inui A, Sogo T, Tateno A, Shimokawa R, Fujisawa T. Tears from children with chronic hepatitis B virus (HBV) infection are infectious vehicles of HBV transmission: Experimental transmission of HBV by tears, using mice with chimeric human livers. J Infect Dis 2012;206(4):478485. https://doi.org/10.1093/infdis/jis293

24. Hu DJ, Kane MA, Heymann DL. Transmission of HIV, hepatitis B virus, and other bloodborne pathogens in health care settings: A review of risk factors and guidelines for prevention. Bull World pathogens in health care settings: A review of risk factors and guidelines for prevention. Bull World
Health Organ 1991;69(5):623-630. https://www.ncbi.nlm.nih.gov/pmc/articles/PMC2393247/

25. Goh KT, Ding JL, Monteiro EH, Oon CJ. Hepatitis B infection in households of acute cases. J Epidemiol Community Health 1985;39(2):123-128. https://doi.org/10.1136/jech.39.2.123

26. Corden S, Ballard AL, Ijaz S, et al. HBV DNA levels and transmission of hepatitis B by health care workers. J Clin Virol 2003;27(1):52-58. https://doi.org/S1386653202001270

27. Komiya Y, Katayama K, Yugi H, et al. Minimum infectious dose of hepatitis B virus in chimpanzees and difference in the dynamics of viremia between genotype A and genotype C. Transfusion 2008;48(2):286-294. https://doi.org/10.1111/j.1537-2995.2007.01522.x

28. Tabuchi A, Tanaka J, Katayama K, et al. Titration of hepatitis B virus infectivity in the sera of pre-acute and late acute phases of HBV infection: Transmission experiments to chimeric mice with human liver repopulated hepatocytes. J Med Virol 2008;80(12):2064-2068. https://doi.org/10.1002/jmv.21320

29. Arulogun OS, Adesoro MO. Potential risk of HIV transmission in barbering practice amon professional barbers in Ibadan, Nigeria Afr Health Sci 2009:9(1):19-25. https:/www ncbinlm nih. gov/pmc/articles/PMC2932524/ (accessed 12 March 2018).

30. Russell AD, Hugo WB, Ayliffe GAJ. Principles and Practices of Disinfection, Preservation and Russell AD, Hugo WB, Ayliffe GAJ. Principles
Sterilization. Oxford: Blackwell Science, 1999.

31. Weber DJ, Barbee SL, Sobsey MD, Rutala WA. The effect of blood on the antiviral activity of sodium hypochlorite, a phenolic, and a quaternary ammonium compound. Infect Control Hosp Epidemiol hypochlorite, a phenolic, and a quaternary ammonit
1999;20(12):821-827. https://doi.org/10.1086/501591

32. Omidbakhsh N, Sattar SA. Broad-spectrum microbicidal activity, toxicologic assessment, and materials compatibility of a new generation of accelerated hydrogen peroxide-based environmenta surface disinfectant. Am J Infect Control 2006;34(5):251-257. https://doi.org/10.1016/ ajic.2005.06.002

Accepted 24 August 2017 